\title{
Status of Surface Water from Selected Areas of Coastal Guyana and the Removal of Toxic Contaminants, using a Suitable Adsorbent
}

\section{Advances in Earth and Environmental Science}

Research Article

Jagessar $\mathbf{R C}^{1^{*}}$, Prince $\mathbf{C}^{2}$

${ }^{1}$ Department of Chemistry, University of Guyana, Turkeyen Campus, University of Guyana

${ }^{2}$ Final Year Research Chemistry Student, Turkeyen Campus, University of Guyana

\author{
*Correspondence authors \\ Jagessar RC \\ Department of Chemistry \\ University of Guyana \\ Turkeyen Campus \\ Guyana
}

Submitted : 6 Dec 2021 ; Published : 30 Dec 2021

\begin{abstract}
This study was done, to compare the status of surface water taken from two different locations within the coastal areas of Guyana, before and after treatment with a peanut biomass adsorbent. The water samples were collected from Parika Bushy Park and Vreed En Hoop and stored in water bottles. It was then submitted for physical and chemical analyses using versatile standard methods. These include test for heavy metals cations $(\mathrm{Pb}, \mathrm{Fe}, \mathrm{Zn}$, $\mathrm{Cd}$, and Al), test for anions (chlorides, sulphates, phosphates) along with the physical parameters (turbidity and conductivity). There was no detection for the toxic lead and cadmium cations at either surface water. The adsorbent was effective in removing $\mathrm{Fe}^{2+}$ at both surface water as there was a decrease in concentration. For example, at Vreed En Hoop surface water, the concentration of $\mathrm{Fe}^{2+}$ decrease from $(8.42 \pm 2.14 \mathrm{mg} / \mathrm{L})$ to $(5.56 \pm 3.42 \mathrm{mg} / \mathrm{L})$, $33.96 \%$ reduction, after treatment with the adsorbent. For the $A l^{3+}$ cation, there was a decrease in the concentration of $\mathrm{Al}^{3+}$ from $(5.97 \pm 0.67 \mathrm{mg} / \mathrm{L})$ to $(4.20 \pm 1.90 \mathrm{mg} / \mathrm{L}), 29.65 \%$. For the $\mathrm{SO}_{4}^{2-}$ and $\mathrm{Cl}^{-}$anions, there was a decrease in concentration at the Vreed En Hoop surface water, after treatment with the adsorbent. With $\mathrm{SO}_{4}^{2-}$, the concentration decrease from $346 \pm 3.15 \mathrm{mg} / \mathrm{L}$ to $293 \pm 1.77 \mathrm{mg} / \mathrm{L}, 15.31 \%$, whilst that for chloride, Cl-, decrease from $116 \pm$ $1.75 \mathrm{mg} / \mathrm{L}$ to $102 \pm 1.70 \mathrm{mg} / \mathrm{L}, 12.07 \%$ reduction. Thus, the peanut shell should find application in the removal of selective cations and anions from surface water.
\end{abstract}

Keywords: Adsorbent, Surface Water, Contaminants, Cations, Anions

\section{Introduction}

Water is a universal solvent that sustains all life forms. Much of the current concern with regards to environmental quality is focused on water, because of its importance in maintaining the human health and health of the ecosystem. Surface water is water on the surface of the planet, such as in a stream, river, lake, wetland, or ocean. It can be contrasted with groundwater and atmospheric water [1-7]. Providing sufficient quantities of high quality water to satisfy our domestic, industrial and agricultural needs is an ongoing global problem. Increasing population size, climate change and pollution will only exacerbate the global status. There is no physical shortage of water on the planet earth as it covers $70 \%$ of the globe. However, $97 \%$ of the world water is saline and is thus non-drinkable, $2 \%$ is locked in glaciers and polar ice caps, resulting in $1 \%$ to meet humanity needs. Guyana water need continual monitoring to assess the concentration of toxic elements $[7,8]$. Surface water plays a very vital role in economics and the functioning of ecosystems [9]. In Guyana, surface water is primarily used for agricultural, industrial and commercial purposes. Pollution of surface water, due to industrial effluents and municipal waste in water bodies is a major concern in Georgetown, Linden and many other regions in Guyana.
Surface water is usually rain water that collects in surface water bodies, like oceans, lakes, or streams. Another source of surface water is groundwater that discharges to the surface from springs. Guyana has abundant surface and ground water supplies near all populated centers. Both surface and ground water resources are relied upon for water supply requirements. Heavy amounts of precipitation provide high amounts of surface runoff and ground water recharge. Most of the domestic water supply comes from ground water resources, while most of the water supply for agriculture (such as, sugarcane and rice) and industry comes from surface water.

Surface water pollution occurs when hazardous substances come into contact and either dissolve or physically mix with the water [10-11]. Contamination of surface water can occur when hazardous substances are discharged directly from an outfall pipe or channel or when they receive contaminated storm water runoff. On the other hand, direct discharges can come from industrial sources or from certain older sewer systems that overflow during wet weather. Surface water can also be contaminated when contaminated groundwater reaches the surface through a spring, or when contaminants in 
the air are deposited on the surface water. Contaminated soil particles carried by storm water runoff or contaminants from the air can sink to the bottom of a surface water body, mix with the sediment, and remain [12]. Contamination takes place largely in proximity to manufacturing areas, along main rivers, canals and creeks. Pollutants in surface water can be untreated sewage, anthropogenic activities, industrial effluents and agrochemical (fertilisers and pesticides) run-off. Excess fertilisers, when applied to crops are washed downstream and finds its way to water ways causing eutrophication. The same may be said of pesticides, which are detrimental to marine life. Others include organic compounds, heavy metals, bacteria, fungi, and petroleum products, hazardous material, sewage, leakage from landfills, heavy metals such as mercury from gold mining, lead and cadmium from anthropegenic activities. These pollutants found in the water ways, make it harmful to human health and causing a number of short and or long term illnesses. These illnesses can range from; cancers of the bladder, kidney, skin, liver, neurologic and neurobehavioral disorders, cholera, hepatitis, typhoid, and diarrhea [13]. Thus, the levels of concentration of cations/ anions must be controlled in our water bodies [14-16]. Other toxic metal cations and anions in water include cadmium, mercury and lead [14-16]. These toxic metal ions must be below the international accepted threshold values. Heavy metals and ions enter into the water from the various sources. But while some of these metals are important as micronutrients, having them in very high concentrations in the food chain can cause toxicity and can further impact the environment where aquatic ecosystems and their users can become endanger [17-18].

There is minimal purification of water via filtration and chlorination, which occurs inconveniently in Georgetown, Guyana, only when supplies are available and operational. To combat these issues in Guyana, the Guyana Water Inc. (GWI) was established with the task of delivering safe water for improved public health and sustainable economic development. Water pollution continues to be an emergent concern in Guyana and subsequent action is needed to help reduce and further resolve the problem. Thus, by improving the water treatment systems, Guyana can reduce and eliminate these issues [19].

Due to the contamination of these water ways with cations and anions, a proposed adsorbent of peanut shells will be intended to use as an alternative in the removal of these toxic contaminants. The peanut shell is choosen as an adsorbent for the treatment of the selected water from Guyana for several reasons. These include its low cost, its high porosity, pore size (micro-pores volume in the range $0.3-0.44 \mathrm{~nm}$ ) and high adsorptive capacities, Fig. 1.0. This can significantly improve Guyana"s water quality and further help the Caribbean and even expand internationally. This alternative will aid in reducing the concerns over high operating and capital costs, efficiency and the need for secondary treatment [20]. Another, equally important point is that the raw materials (peanuts) are grown and cultivated locally in Guyana and across the Caribbean, which makes it even more accessible and a good choice as an adsorbent. The peanut plant grows best in loose sandy soil under warm-weather conditions. This leguminous crop requires adequate moisture for good yield. Depending on the variety, it grows from 6 to 30 inches in height. Some plants grow upright while others spread (NAREI Communications Unit, 2016) [21]. The process of transference of mass where one or more substances (adsorbate) present in a gaseous or liquid stream is transferred in a selective way to the surface of a porous solid (adsorbent) is known as the adsorption method. This method is widely used in the treatment of water, being an eco-friendly and economically viable technology to remove organic pollutants with proven efficiency of $99.9 \%$ from several studies. Adsorbents can be of two types; natural and synthetic adsorbents [22]. The peanut shell is expected to not only remove dangerous heavy metals and ions but also be a cheaper ecofriendly approach.

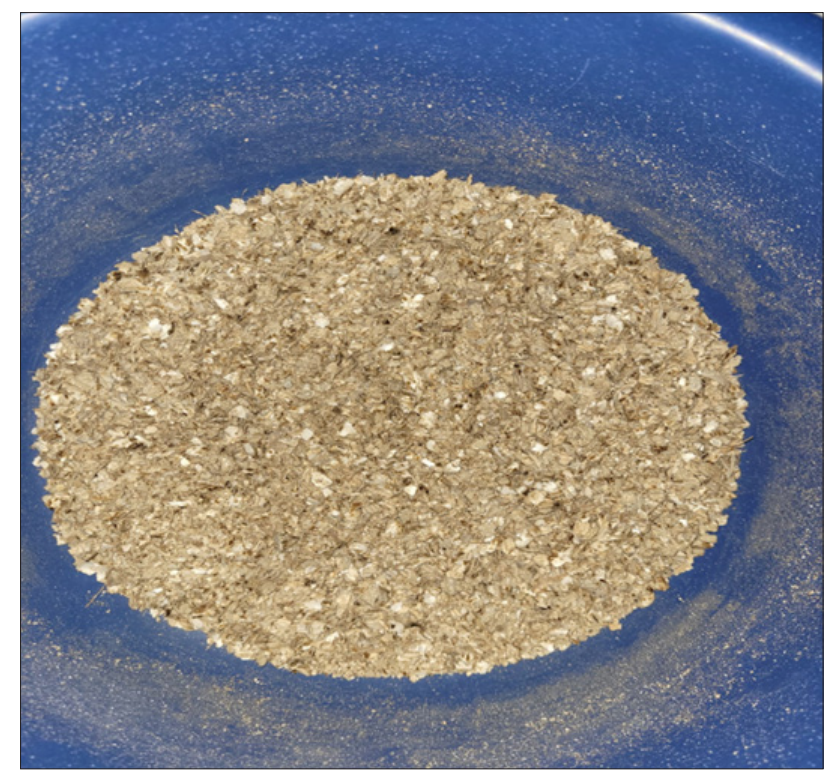

Figure 1.0 : Image showing the blended peanut shells

There are a few reports on the removal of metal ions using peanut shells as adsorbent. For example, the biosorption of $\mathrm{Cr}$ (VI) ions from aqueous solution by peanut shell (PNS) biosorbent. A pseudo-second order equation best described adsorption kinetics. Maximum adsorption was achieved at $\mathrm{pH} 2.0$ and 3.0. There was favorable adsorption of $\mathrm{Cr}(\mathrm{VI})$ on PNS adsorbent. The adsorption capacity was found to be 4.32 $\mathrm{mg} / \mathrm{g}$ at $313 \mathrm{~K}$. The process has been found to be endothermic, non spontaneous and entropy driven [23]. The efficiency of chemically modified peanut shell (CMPS) on adsorbing cadmium ions was evaluated using a batch system mode. The kinetic, isothermal and thermodynamic models were applied to study adsorption properties. The $\mathrm{pH}$, adsorption time and initial concentrations were followed. Under the indoor temperature $\left(25^{\circ} \mathrm{C}\right)$, when $\mathrm{pH}$ was 8 and adsorption time was $40 \mathrm{~min}$, the adsorption capacity reached the maximum, $40.10 \mathrm{mg} / \mathrm{g}$. The kinetic adsorption was better described by pseudo-secondorder rate model. The theoretical maximum adsorption capacity calculated by Langmuir equation were 95.24, 105.26, $109.89 \mathrm{mg} / \mathrm{g}$ at $283 \mathrm{~K}, 298 \mathrm{~K}$ and $308 \mathrm{~K}$ respectively [24]. The use of natural adsorbents to remove heavy metal ions from 
water, have been finding increasing applications [25-26].

Guyana is a sovereign state on the northern mainland of South America and is also part of the Caribbean region. Guyana (83,000 square miles) is bordered by the Atlantic Ocean to the north, Brazil to the south and southwest, Suriname to the east and Venezuela to the west, Fig 1.0. Fig 2.0 is a map of two of the selected areas of coastal Guyana. Its an Amerindian word, meaning land of many waters [19].

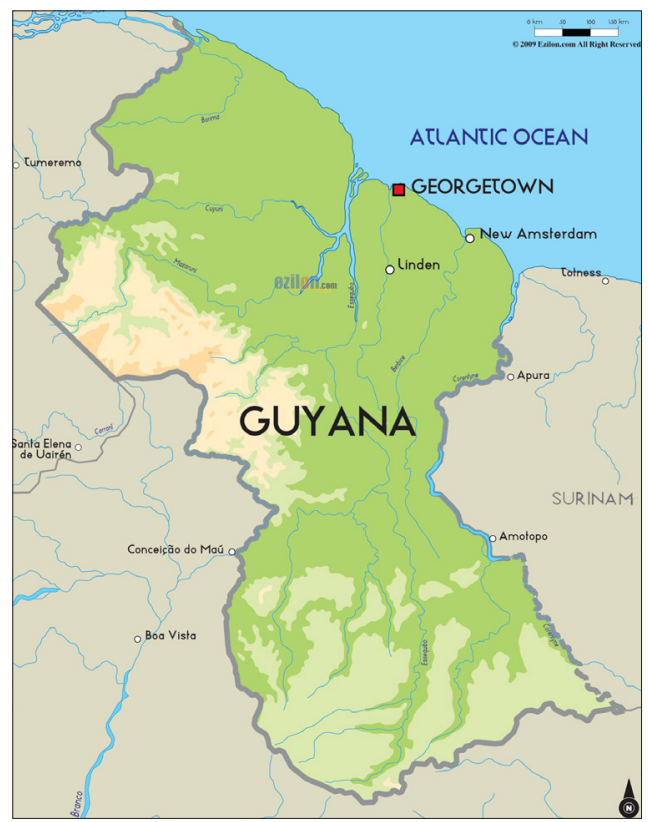

Figure 2.0 : Map of Guyana. www.worldatlas.com/webimage/ countrys/samerica/gy.htm

Thus, the general objective of the research is to identify and evaluate the status of surface water from selected areas of coastal Guyana (Vreed En Hoop stelling and Bushy Park) and to remove toxic contaminants using peanut shells as a cheaper ecofriendly adsorbent alternative. Also, to identify the optimal percentage level of heavy metals, cations \& anions, along with the turbidity and conductivity within the water samples.

\section{Methodology}

\section{Acquiring materials}

The testing process took placed in chronological order. Firstly, special plastic bottles to store the water samples taken from Vreed en hoop, and Bushy Park Parika, Guyana were purchased. These samples were sent to Guyana Sugar Cooperation INC (GUYSUCO) central laboratory for physical and chemical analyses using versatile standard procedures/methods.

\section{Storage of Materials}

The water samples from the two different locations were stored in eighteen (18) separate plastic bottles. Six bottles for each site and another three bottles for the filtrate of the treated water ( 3 for treated water and 3 for untreated water along with another three to collect the filtrate). The samples were labeled and stored in a secure cool environment away from any other foreign body of water so as to avoid any external cross contamination.
Testing

- The testing of the water samples were done at the Guyana Sugar Cooperation INC (GUYSUCO) central laboratory in triplicates for each parameter. The tests will include;

Test for heavy metals ( $\mathrm{Pb}, \mathrm{Fe}, \mathrm{Zn}, \mathrm{Cd}, \mathrm{Al})$ [Nitric Acid digestion by F-AAS]

Test for anions $\left(\mathrm{SO}_{4}^{2}, \mathrm{PO}_{4}\right.$ : Acid digestion by Spectrophotometry (UV-VIS)

Test for Chlorides: Mohr Argentometric- titrimetry

\section{Method}

A total of $3(3 \times 3=27)$ bottles were required for this project. The water samples were collected in triplicates of two (2) from the two selected areas of Guyana's Coastland, six bottles for each site, plus another three bottles for the filtrate of the treated water ( 3 for treated water and 3 for untreated water and another three to collect the filtrate). The samples were labeled and stored in a cool environment. The samples were then submitted immediately for analyses at GUYSCO. One of the Triplicates set of water was treated with the adsorbent and filtered. For the untreated and treated water, the water samples were filtered, using a pore diameter membrane filter. After filtration, the filtrate was transferred to a beaker. $5 \mathrm{ml}$ of Conc. $\mathrm{H}_{2} \mathrm{SO}_{4}$ and several boiling chips was added. The contents of the beaker was brought to a slow boil and evaporated onto a hot plate to the lowest volume $(10 \mathrm{ml})$ to initiate precipitation. Heating continued with concomitant addition of $\mathrm{HNO}_{3}$ until digestion was completed. Drying of the sample was avoided. The flask was then washed with water and contents filtered. The filtrate was transferred to a $100 \mathrm{ml}$ volumetric flask and made up to the mark. Portions of the solution were then taken for metal ion determinations using Flame Atomic Spectroscopy. For each metal analyzed, appropriate standard solution of known metal concentration in the water with a matrix similar to the sample was prepared.

\section{Data Analysis}

From the results collected from each test, comparisons and calculations was done to identify trends and possible patterns. The data was placed into tables and graphs to be represented and analyzed. Recommendations were made based on the data gathered from each of these tests.

\section{Statistical Analysis}

Analysis of variance (ANOVA) One way without replication was done. This is a statistical technique used to find out if the means of two or more groups are significantly different from each other. ANOVA checks the impact of one or more factors by comparing the means of different samples. It splits an observed aggregate variability found inside a data set into two parts: systematic factors and random factors. The systematic factors have a statistical influence on the given data set, while the random factors do not. Analysts use the ANOVA test to determine the influence that independent variables have on the dependent variable in a regression study (Kenton, 2019). 
Results

\begin{tabular}{|l|l|l|l|l|}
\hline $\begin{array}{l}\text { Parameter } \\
{[\text { Metals }]}\end{array}$ & $\begin{array}{l}\text { Untreated } \\
\text { [Parika Bushy Park] } \\
\text { Ave }(\mathrm{mg} / \mathrm{L})\end{array}$ & $\begin{array}{l}\text { Treated } \\
{[\text { Parika Bushy Park }]} \\
\text { Ave }(\mathrm{mg} / \mathrm{L})\end{array}$ & $\begin{array}{l}\text { Treated } \\
{[\text { Parika Bushy Park] }} \\
\text { Ave }(\mathrm{mg} / \mathrm{L})\end{array}$ & $\begin{array}{l}\text { Treated } \\
\text { [Vreed En Hoop] } \\
\text { Ave }(\mathrm{mg} / \mathrm{L})\end{array}$ \\
\hline $\mathrm{Pb}$ & $\mathrm{Nd}$ & $\mathrm{Nd}$ & $\mathrm{Nd}$ & $\mathrm{Nd}$ \\
\hline $\mathrm{Fe}$ & $4.21 \pm 0.95$ & $3.82 \pm 0.52$ & $8.42 \pm 2.14$ & $5.56 \pm 3.42$ \\
\hline $\mathrm{Al}$ & $3.63 \pm 0.55$ & $4.25 \pm 0.71$ & $5.97 \pm 0.67$ & $4.20 \pm 1.90$ \\
\hline $\mathrm{Cd}$ & $\mathrm{Nd}$ & $\mathrm{Nd}$ & $\mathrm{Nd}$ & $\mathrm{Nd}$ \\
\hline $\mathrm{Zn}$ & $\mathrm{Nd}$ & $\mathrm{Nd}$ & $\mathrm{Nd}$ & $\mathrm{Nd}$ \\
\hline
\end{tabular}

Table 1.0: Shows the concentration of the metal cations for the two selected areas in the untreated and treated water with the adsorbent.

\begin{tabular}{|l|l|l|l|l|}
\hline $\begin{array}{l}\text { Parameter } \\
\text { [Anions] }\end{array}$ & $\begin{array}{l}\text { Untreated } \\
\text { [Parika Bushy Park] } \\
\text { Ave }(\mathrm{mg} / \mathrm{L})\end{array}$ & $\begin{array}{l}\text { Treated } \\
\text { [Parika Bushy Park] } \\
\text { Ave }(\mathrm{mg} / \mathrm{L})\end{array}$ & $\begin{array}{l}\text { Untreated } \\
\text { [Vreed En Hoop] } \\
\text { Ave }(\mathrm{mg} / \mathrm{L})\end{array}$ & $\begin{array}{l}\text { Treated } \\
\text { [Vreed En Hoop] } \\
\text { Ave (mg/L) }\end{array}$ \\
\hline $\mathrm{SO}_{4}^{-}$ & $5.00 \pm 3.80$ & $6.62 \pm 3.93$ & $346 \pm 3.15$ & $293 \pm 1.77$ \\
\hline $\mathrm{PO} 4$ & $0.38 \pm 1.84$ & $1.43 \pm 2.80$ & $0.80 \pm 0.75$ & $2.33 \pm 1.72$ \\
\hline $\mathrm{Cl}^{-}$ & 3.55 & Nil & $116 \pm 1.75$ & $102 \pm 1.70$ \\
\hline $\mathrm{EC}_{\mathrm{W}}$ & 0.19 & $0.18 \pm 3.21$ & $6.47 \pm 0.09$ & $6.30 \pm 1.08$ \\
\hline
\end{tabular}

Table 2.0: Shows the concentration of the metal anions for the two selected areas in the untreated and treated water with the adsorbent

\begin{tabular}{|l|l|}
\hline Cations and Anions & Health based guideline by the WHO (mg/l) \\
\hline $\mathrm{Al}$ & $0.1-0.2$ \\
\hline $\mathrm{Fe}$ & 3 \\
\hline $\mathrm{Pb}$ & $1.0 \times 10^{-2}$ \\
\hline $\mathrm{Cd}$ & $3.0 \times 10^{-3}$ \\
\hline $\mathrm{Zn}$ & 3 \\
\hline $\mathrm{PO}^{3-}$ & 5 \\
\hline $\mathrm{SO}_{4}^{2-}$ & 250 \\
\hline $\mathrm{Cl}^{2}$ & 250 \\
\hline $\mathrm{ECW}^{-}$ & 256 \\
\hline
\end{tabular}

Table 3.0: showing the health based guideline by the World Health Organization for cations and anions within surface water

\begin{tabular}{|c|c|c|c|c|}
\hline $\begin{array}{l}\text { Parameter } \\
\text { [metal cations; Fe, Al, Pb, Cd, Zn] }\end{array}$ & $P$ value & $F$ value & F Crit & Significance \\
\hline \multicolumn{5}{|l|}{ Conc. Between the two areas } \\
\hline Parika Bushy Park vs Vreed En Hoop & 0.217576 & 1.75769192 & 5.117355029 & No significance \\
\hline Untreated vs Treated & $1.92 \times 10^{-5}$ & 26.728966 & 3.178893104 & Significant \\
\hline \multicolumn{5}{|l|}{ Conc. for Vreed En Hoop } \\
\hline Untreated vs Treated & 0.008482002 & 33.01378914 & 9.276628153 & Significant \\
\hline \multicolumn{5}{|l|}{ Conc. for Parika, Bushy Park } \\
\hline Untreated vs Treated & 0.012146 & 81.32969292 & 19 & Significant \\
\hline
\end{tabular}

Table 4.0: Showing the two Factor ANOVA without replication Analyses results for the metal cations; $\mathrm{Fe}, \mathrm{Al}, \mathrm{Pb}, \mathrm{Cd}, \mathrm{Zn}$ 


\begin{tabular}{|c|c|c|c|c|}
\hline Parameter: $\left[\mathrm{PO}_{4}^{-}, \mathrm{SO}_{4}^{2-}\right.$ and $\mathrm{Cl}^{-}$anions] & $P$ value & $F$ value & $F$ Crit & Significance \\
\hline \multicolumn{5}{|l|}{ Conc. Between the two areas } \\
\hline Parika Bushy Park vs Vreed En Hoop & 0.261385177 & 1.602044704 & 5.050329058 & No significance \\
\hline untreated vs treated & $2.1617 \times 10^{-5}$ & 143.1408508 & 5.050329058 & Significant \\
\hline \multicolumn{5}{|l|}{ Conc. for Parika, Bushy Park } \\
\hline Untreated vs Treated & 0.769781 & 0.14308129 & 161.4476388 & No significance \\
\hline \multicolumn{5}{|l|}{ Conc. for Vreed En Hoop } \\
\hline Untreated vs Treated & 0.045933 & 191.429408 & 161.4476388 & Significant \\
\hline
\end{tabular}

Table 5.0: showing the two Factor ANOVA Analyses without replication results for the anions; $\mathrm{PO}_{4}^{3-}, \mathrm{SO}^{2-}{ }_{4}$, and $\mathrm{Cl}^{-}$

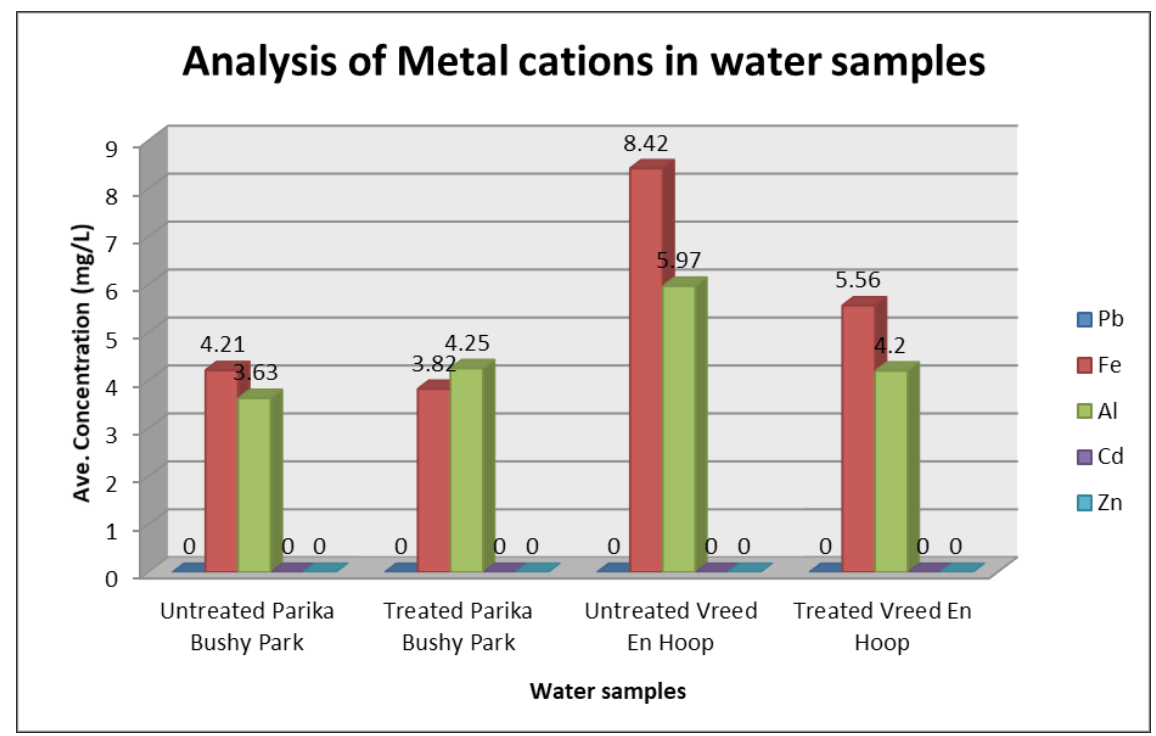

Graph 1: Column graph showing the comparative results in $\mathrm{mg} / \mathrm{L}$ of the untreated samples versus the treated samples from Parika, Bushy Park and Vreed En Hoop with the adsorbent in the removal of selective metals within the water.

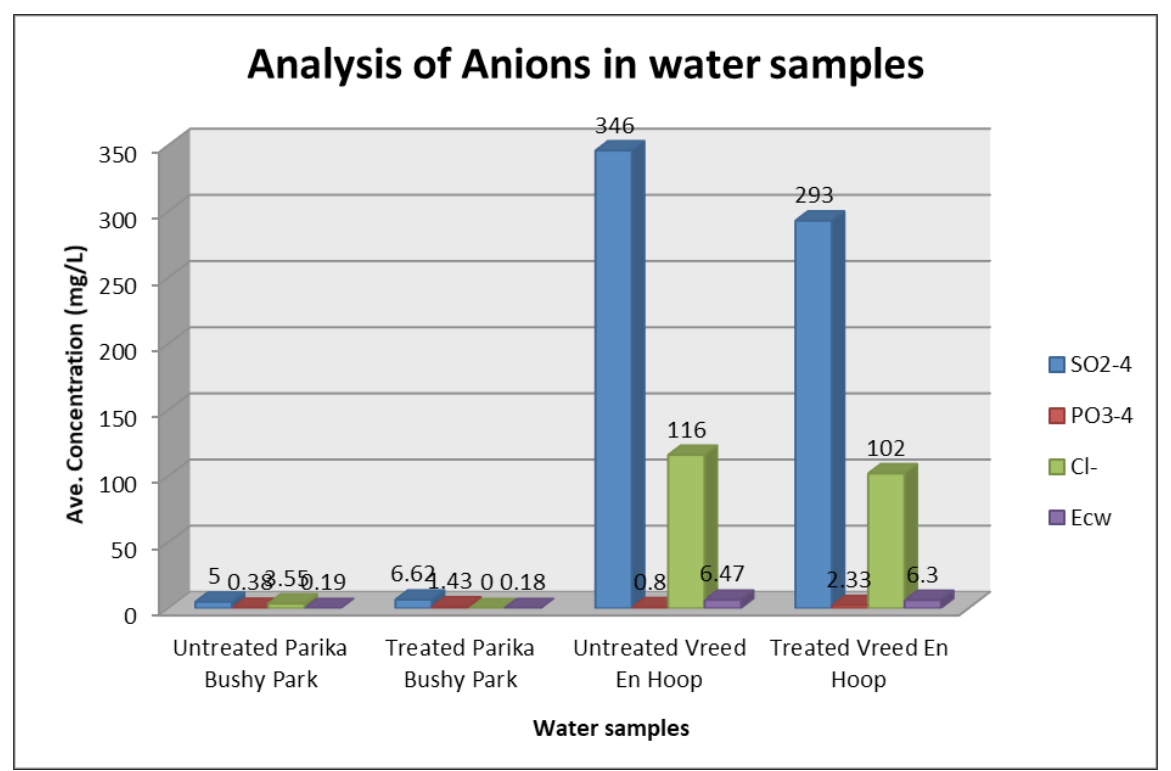

Graph 2.0: Column graph showing the comparative results in $\mathrm{mg} / \mathrm{L}$ of the untreated samples versus the treated samples from Parika, Bushy Park and Vreed En Hoop with the adsorbent in the removal of selective anions and cations within the water 


\section{Discussion}

Table 1.0 shows the concentration of the metal cation for the two selected areas in the untreated and treated $\mathrm{H}_{2} \mathrm{O}$, with the peanut shell adsorbent. It was noticeable that there was no detection for $\mathrm{Pb}, \mathrm{Cd}$ and $\mathrm{Zn}$. $\mathrm{Pd} \& \mathrm{Cd}$ are noteworthy toxic. However, there was detection for Fe for untreated and treated water in all instances. For Fe, this range from $(3.82 \pm 0.52$ $\mathrm{mg} / \mathrm{L})$ to $(8.42 \pm 2.14 \mathrm{mg} / \mathrm{L})$. For $\mathrm{Al}$, this range from $(3.63$ $\pm 0.55 \mathrm{mg} / \mathrm{L})$ to $5.97 \pm 0.67 \mathrm{mg} / \mathrm{L})$. It was noticeable that for the Parika Bushy Park and Vreeden Hoop water, there was a decrease in the concentration of the $\mathrm{Fe}^{2+}$ cation. $\mathrm{For}^{3+}$, it was noticeable that there was an increase in the concentration of $\mathrm{Al}^{3+}$ for treated $\mathrm{H}_{2} \mathrm{O}$, compared with untreated $\mathrm{H}_{2} \mathrm{O}$, at Parika Bushy Park. However, for Vreed En Hoop untreated $\mathrm{H}_{2} \mathrm{O}$, there was a decrease in the concentration of the $\mathrm{Al}^{3+}$ cation from $5.97 \pm 0.67 \mathrm{mg} / \mathrm{L}$ to $4.20 \pm 1.90 \mathrm{mg} / \mathrm{L}$, after treatment with the adsorbent.

Table 2.0 shows the concentration of anions for the two selected areas in the untreated and treated water, with the adsorbent. $\mathrm{SO}_{4}^{2-}, \mathrm{PO}_{4}^{2-}, \mathrm{Cl}^{-}$. It was noticeable that there was a decrease in the concentration of $\mathrm{SO}_{4}^{2-}$ and $\mathrm{Cl}^{-}$at Vreed En Hoop untreated water, after treatment with the adsorbent. For the Parika Bushy Park, there was an increase in concentration of the sulphate and phosphate anions. The increase in phosphate anions concentration is probably due to some form of leaching from the adsorbent. Table 3.0 shows the two factor ANOVA without replication Analysis results for concentration of cations for $\mathrm{Fe}$, $\mathrm{Al}, \mathrm{Pb}, \mathrm{Cd}$ and $\mathrm{Zn}$.

It was found that the P-value was greater than 0.217 , indicating that there wasn't any significant differences in the concentration of cations and anions between the two selected areas. When the concentration of the cations and anions were compared for untreated vs. treated water of Parika Bushy Park vs. Vreed en Hoop, it was found that the P-value (1.92 x 10$\left.{ }^{5}\right)$ is significantly $<0.05$, indicating significant differences. In addition, the F-value (26.75) is significantly greater than F critical, indicating significant differences in the concentration of the cations. When the concentration of cations and anions was compared for Parika vs. Bushy Park, it was found that the $\mathrm{P}$-value is $<0.05$.

\section{Conclusion}

The status of the surface water from two different locations, Parika Bushy Park and Vreed En Hoop within the coastal areas of Guyana before and after treatment with a peanut shell adsorbent has been analysed. Analyses were done for $\mathrm{Pb}, \mathrm{Fe}, \mathrm{Zn}, \mathrm{Cd}$ and $\mathrm{Al}$ and for anions: chlorides, sulphates and phosphates. In addition, physical parameters (turbidity and conductivity) were analysed. There was no detection for the toxic lead and cadmium cations at either surface water. The adsorbent was effective in removing $\mathrm{Fe}^{2+}$ at both surface water as there was a decrease in concentration. For the $\mathrm{Al}^{3+}$ cation, there was a decrease in the concentration of $\mathrm{Al}^{3+}$. For the $\mathrm{SO}_{4}^{2-}$ and $\mathrm{Cl}^{-}$anions, there was a decrease in concentration at the Vreed En Hoop surface water, after treatment with the adsorbent. Thus, the peanut shell should find application in the removal of selective cations and anions from surface water.

\section{Acknowledgements}

Prof RC Jagessar thank GUYSUCO for paid analytical services.

\section{References}

1. Young RA, Bredehoeft JD, Digital simulation for solving management problems with conjunctive groundwater and surface water systems from Water Resources Research 8: 533-536.

2. Eaton AD, Clessicens SL, Greenberg EA (1995) Standard methods for the Examination of Water and Wastewater, $19^{\text {th }}$ ed. United Book Press Inc. Baltimore, Maryland USA 4-48.

3. Eaton AD, AWWA, Chair (1995) "Standard methods for the examination of Water and Wastewater", $19^{\text {th }}$ ed. United Book Press Inc. Baltimore, Maryland USA 4-67.

4. Booth RL (1983) Methods for the Chemical analysis of Water and Wastes, $2^{\text {nd }}$ ed. Environmental Monitoring and Support Laboratory, Office of Research and Development, U.S. Environmental Protection Agency, Cincinnati: Ohio $45268 ; 352$.

5. Hach Company, Water Analyses handbook, $3^{\text {rd }}$ ed. Loveland Colorado, USA; 1997, 304-307.

6. Radojevic M, Bashkin VN (1999) "Practical Environmental Analysis", Royal Society of Chemistry, Cambridge UK.

7. Elliot S (2008) Testing the water, Royal Society of Chemistry, RSC, News Magazine 12: 12-13.

8. Williams N (2010) Guyana Times, a News Magazine.

9. Khublaryan MG (1994) Surface Waters: Rivers, streams, lakes and wetlands. Encylopaedia of Life Support Systems. Types and Properties of Water 1.

10. EPA (2011). Drinking water contaminants. Retrieved September 13, 2015, from http://www.epa.gov/superfund/ students/website/srfcspikl.htm.

11. EPA (2013) Total Nitrogen. United States: Environmental Protection Agency.

12. Carr GM, Neary JP (2006) Water Quality for Ecosystem and Human Health. Burlington: United Nations Environment Programme Global Environment Monitoring System / Water Programme 132.

13. Tchounwou PB, Yedjou CG, Patlolla AK, Sutton DJ (2012) Heavy metal toxicity and the environment. Retrieved from Experientia Supplementum 133-164.

14. Ho Yu Ming, "Environmental Toxicology: Biological and Health Effects of Pollutants, second edition, CRC Press, Boca Raton, London 185-223.

15. Trevor AJ, Katzung BG, Masters SB (2005) Katzung \& Trevor's Pharmacology, $7^{\text {th }}$ edition, a Lange Medical Book, McGraw-Hill, USA 491-497.

16. Zacarias I, Carmen G Yáñez, Magdalena Araya, Chinwe Oraka, Manuel Olivares, et al. (2001) Determination of the taste threshold of copper in water. Chemical Senses 26: 85-89. 
17. Prabu PC (2009) "Impact of heavy metal contamination of Akaki river of Ethiopia on soil and metal toxicity on cultivated vegetable crops," Retrieved from Electronic Journal of Environmental, Agricultural and Food Chemistry 8: 818-827.

18. Kane S, Lazo P, Vlora A Eds, Ohrid M (2012) “Assessment of heavy metals in some dumps of copper mining and plants in Mirdita Area, Albania," in Proceedings of the $5^{\text {th }}$ International Scientific Conference on Water, Climate and Environment.

19. US Army Corps of Engineers (1998) WATER RESOURCES ASSESSMENT OF GUYANA.

20. Fierro V, Torné-Fernández V, Montané D, Celzard A (2008) Adsorption of phenol onto activated carbons having different textural and surface properties. Microporous and Mesoporous Materials 111: 276-284.

21. NAREI Communications Unit, 2016.

22. Ali I, Asim M, Khan TA (2012) Low cost adsorbents for the removal of organic pollutants from wastewater. Journal of Environmental Management 113: 170-183.

23. YAS IL, Ahmad M, Saeed A (2013) Removal of Cr (VI) from Aqueous Solutions Using Peanut shell as Adsorbent. J Chem Soc Pak 35: 760.

24. Liang Xu, Zhuang Z (2014) Removal of cadmium ions from aqueous solution using chemically modified peanut shell Journal of Chemical and Pharmaceutical Research, JCPRC 6: 649-653.

25. Sobhanardakani S, Parvizimosaed H, Olyaic E (2013) "Heavy metals removal from Wastewaters, using organic solid waste-rice husk", Environ Sci Pollution Res 20: 5265-5271.

26. Amarsinghe, BMWPK, Williams RA (2007) "Tea waste as a low cost adsorbent for the removal of $\mathrm{Cu}$ and $\mathrm{Pb}$ from wastewater", Chem Eng J 132: 299-309.

Copyright: (2021 Jagessar RC. This is an open-access article distributed under the terms of the Creative Commons Attribution License, which permits unrestricted use, distribution, and reproduction in anymedium, provided the original author and source are credited. 